\title{
WAS JESUS VOLGENS LUKAS SE VERTELLING 'N POLITIEKE FAKTOR?
}

Jan A. du Rand

Departement Bybelkunde

Randse Afrikaanse Universiteit

JOHANNESBURG

\begin{abstract}
Was Jesus in any sense politically involved in the social and cultural activities of his day? The answer is yes and no! An analysis of the social-political situation in Palestine during Jesus' ministry shows that political aspirations and religious convictions were interlaced. It was a complex situation in which the political, social, economical and religious background contributed to the understanding of the message of Jesus. The Romans, pnests, Sadducees, Pharisees, Zealots and Essenes, each chose their own social-political solution.

According to Luke, Jesus had his own stance regarding the poor, the infirm, and aspects like riches oppression, injustice and violence. He manifested a strong concem for the poor; called upon those with sumplus possessions to use them to benefit the poor and recommended to his disciples to find ways to enable the poor to participate fully in community life (cf. Luke 14:12-14).

Jesus also did not submit to the social pattems and political practices to which the Romans were committed. Although he rejected violence, as manifested in the attiude of the Zealots, Jesus was at least patentially a serious threat to Roman rule in Palestine in propagating a new community style of love and humility.
\end{abstract}

\section{ORIËNTERENDE STANDPUNTTNNAME}

Die doel van hierdie artikel is om vanuit politieke en sosiale aktualiteit as blikpunt terug te blaai na die boodskap van en oor Jesus soos Lukas dit beskryf. Dit mag egter nooit ontaard in 'n soeke na 'n soort imitatio-Jesusboodskap om enige hedendaagse ideologiese sieninge te regverdig nie. Enkele Lukaanse penstrepe oor die relevansie van die Jesus-boodskap vir sosiale en politieke toepasbaarheid bly egter rigtinggewend in enige gelowige opinievorming.

Die keuse val op die Lukasevangelie omdat dit voor-die-hand-liggend 'n besondere sensitiwiteit vir sodanige sake toon. Die gegewens is ook geselekteer ter wille van toepasbaarheid.

Standpunte oor Jesus se betrokkenheid by die sosiale en politieke problematiek van sy dag loop werklik wyd uiteen: aan die een kant is daar sommige wat meen dat Jesus Hom ten volle vereenselwig het met die Selote (vgl. Brandon, 1967:367). Richardson 
(1973:19v) het aangetoon dat die gedagte sy oorsprong reeds by Reimarus gehad het (vgl. Bammel, 1984: 11 e.v.). Daarteenoor het Cullmann egter oortuigend bewyse aangevoer dat Jesus nie noodwendig 'n Seloot was of Hom daarmee geassosieer het nie (1970:36v). Paupert (1969:27) en Brown (1969:19) huldig sulke sterk standpunte oor Jesus se politieke betrokkenheid dat hulle Hom selfs "Mahatma Jesus" noem!

In die beoordeling van standpunte het dit geblyk dat vooropgestelde hermeneutiese oriëntasies verdere resultate bepaal. Daarom is 'n eksegeties-gefundeerde teologiese kyk na die problematiek weer eens noodsaaklik.

\section{JESUS SE BETROKKENHEID MOET BEOORDEEL WORD TEEN DIE AGTERGROND VAN 'N BREë SOSIO-POLITIEKE SITUASIE}

\section{$2.1 \quad$ Politieke faktore}

Jesus moes daarmee rekening hou dat die Joodse bevolking van Palestina na elke grashalm sou gryp om politieke seggenskap vir hulle self te bekom. In 175 v.C. het 'n Joodse groep, die Makkabeërs, deur 'n gewapende oorname die beheer by die Seleusiede oor Palestina oorgeneem. Dit het nie net politieke seggenskap beteken nie maar ook kulturele en godsdienstige vryheid (vgl. 1 Makk. 1-9:22; 2 Makk. 4-15; Josefus; Ant 12,3-14,3). Die Makkabeërs met hul invloed in die samelewing sou dus alles in hul vermoẽ doen om die politieke en religieuse beheer te behou. Die nagevolge hiervan was dat hulle hulle deeglik teen Jesus se optrede verset het. Die Makkabeërs het hulleself selfs as hoëpriesters aangestel. Die interne stryd oor leierskap het egter tot hulle val gelei. Dit het gebeur toe Hyrkanus II en sy bondgenoot Antipater met behulp van Rome die oorhand gekry het. Op só 'n wyse het Rome 'n vastrapplek in Palestina gekry. Dié vurige Joodse nasionalisme wat tot die Makkabese opkoms gelei het, het later soms op venynige wyse gereageer teenoor een van sy eie Joodse seuns, Jesus van Nasaret.

Rome stel toe vir Herodus (die Grote), seun van Antipater, aan bo 'n Joodse Hasmoneaanse koning. Herodus voer 'n militêre skrikbewind teen die Jode en maak sommige van hulle leiers dood. Hy probeer egter deur religieuse toegewings, soos dat die Jode hulle eie tempelbelasting kon vorder en die tempel kon vergroot, om die Jode se goedgesindheid terug te wen. Selfs sy seuns Argelaus, Antipas en Filippus kon nie die Jode tevrede stel nie. Jesus moes hom telkens vasloop teen die politieke ongelukkigheid van die Jode wat gelei het tot sosiale onrus (vgl. Luk. 13:32).

Rome het tog as toegif toegelaat dat die alledaagse politieke en sosiale lewe van Palestina deur middel van religieuse wette beheer is deur die Joodse Raad. Dit het 
selfs die doodstaf ingesluit. 'n Politieke oortreding teen Rome se gesag het egter nie onder die jurisdiksie van die Sanhedrin geval nie. Aangesien die Joodse Raad hoofsaaklik uit die welgestelde priesterhoofde en Sadduseêrs bestaan het en die kundige Skrifgeleerdes totaal in die minderheid was, het die Raad 'n rykmansbeeld gehad wat allermins byval sou vind by die armes.

Jesus het Palestina betree gedurende 'n tydvak toe die politieke situasie en die sosiale orde 'n laagtepunt bereik het. Die prokurators wat namens Rome geregeer het, het byvoorbeeld geen sensitiwiteit gehad vir die godsdienstige ordereëlings van die Jode nie (vgl. Jeremias, 1969:27). Pilatus se omkopery en teregstellings sonder verhoor het ook geen byval gevind nie - om nie eers van die knellende belastings te praat nie! Marknavorsing onder die Jode sou waarskynlik aangetoon het dat die rol van politieke nasionalistiese aktivis die beste opsie vir Jesus was. Alhoewel Hy'n politieke faktor was, het Hy nie dié opsie gekies nie.

\subsection{Sosiale en ekonomiese faktore}

Gedurende Jesus se omwandeling op aarde was die geskatte Joodse bevolking van Palestina ongeveer 'n halfmiljoen (vgl. McCown, 1962:637). Die ekonomie wat hoofsaaklik gegesteun het op die saai-, vrugte-, vee- en visbedryf was nie in staat om die bevolking genoegsaam te dra nie. Groot dele van die bevolking moes dus 'n armoedige bestaan voer wat verder meegehelp het om sosiale groeperinge teen Rome in opstand te laat kom. Jesus het ook nie aan die bekamping van die armoedevraagstuk as sodanig buitengewone aandag gegee nie. Die polarisasie tussen die ryk Sadduseërs en priesterhoofde teenoor die arm massas het egter'n sosiale werklikheid geskep waarmee Jesus rekening moes hou.

Die Herodiane was hoofsaaklik die grondbesitters wat die massas gekasty het met grondbelastings (vgl. Cassidy, 1978:72). Die priesterhoofde het weer gedeel in die religieuse offerandes en tempelbelastings. Op grond van politieke lojaliteite en godsdienstige plignakoming het die grootste deel van die bevolking dus al hoe meer verarm. Sommige is belas om andere nog ryker te maak. Onder sulke omstandighede het die rykes ook Griekse slawe by die slawe-eienaars gekoop. Joodse slawe kon slegs op 'n vrywillige basis gewerf word en dan moes hulle soos 'n oudste seun in die huishouding opgeneem en behandel word. Die vereiste was deurgaans dat elke slaaf ten volle menswaardige behandeling moes ontvang. Sodanige menswaardige behandeling is deur die Joodse wet bepaal. Alhoewel Jesus nie as sodanig uitsprake gemaak het oor menseregte nie, het Hy hom die beginsels van reg, billikheid en liefde volgens die Joodse wet laat geval. Wanneer oor die sake besin word, kan maklik verkeerdelik afgelei word dat Jesus daaroor geswyg het. Die sosiale situasie het egter 'n bepaalde 
orde daarvoor gehad.

\subsection{Godsdienstige faktore}

Die Joodse persoonlike en sosiale lewe is deur die Mosaïese wet bepaal. Dié wet het ook die politieke en openbare lewe gereël. Jesus moes sy politieke voetwerk ken in 'n samelewing wat grotendeels deur 'n korporatiewe sosiale verantwoordelikheid met sosialistiese trekke gedra is (vgl. Harrelson, 1962:77). Veral die wese, weduwees en vreemdelinge het deur wetgewing sekere voorregte geniet gedurende die sabbatjaar (De Veaux, 1965:75). Uitstaande lenings is selfs afgeskryf (vgl. Deut. 15:1-2) om aan die armes die geleentheid te gee om ten minste weer nuut te kan begin. Die wet het die samelewing dus sosialisties beheer.

Die Joodse volk het hulle eenheid beleef rondom die wet en die sentraliteit van die tempel. Dit het nie net die religieuse lewe beheer nie, maar ook ekonomiese en kulturele voordele ingehou, veral as die pelgrims jaarliks Jerusalem toe gestroom het om offerandes te bring (vgl. Yoder, 1972:46 e.v.).

$\mathrm{Na}$ die wegvoering in ballingskap, weg van die tempel as nasionale simbool, het 'n nuwe samehorigheidsbinding na vore getree, naamlik 'n apokaliptiese gees. Daarvolgens het die Jode gehoop op 'n nuwe toekoms wanneer God hulle reg sal bevestig en hulle ook ekonomies en polities sal verlos. Jesus het klaarblyklik nie aan die Messiasverwagting volgens hulle simboliese universum voldoen nie. Jesus moes egter deeglik rekening hou met die vervlegtheid van die politieke en ekonomiese verwagtinge binne só 'n religieuse raamwerk - met die betekenis en effek van 'n apokaliptiese ingesteldheid in enige samelewing moet deeglik rekening gehou word.

\section{JESUS HET OOK MET INVLOEDRYKE GROEPE PERSONE TE DOENE GEKRY}

Benewens die vermelde faktore is die Palestynse politieke en sosiale opinie ook beslissend beïnvloed deur verskillende persone en groepe persone:

Die hoëpriester het as gevolg van sy posisie in die tempel, asook in die Sanhedrin, 'n beherende posisie ingeneem in die Joodse samelewing. Staatsaangestelde hoekpriesters, soos byvoorbeeld deur Herodes die Grote aangestel, het alles gedoen om Rome te probeer tevrede stel (vgl. Jeremias, 1969:377). Een van die eerste dinge wat die Selote na bewindsoorname in $67 \mathrm{n}$.C. gedoen het, was om weer 'n hoeppriester uit die Sadokitiese geslagslyn aan te stel. Buiten sy verhoor, het Jesus nie direk 
kontak gehad, (waarvan ons weet) met die heersende hoëpriester nie. Jesus wou eerder deur sy optrede en boodskap die nasionalisties-gerigte godsdiens in 'n totaal nuwe geestelike rigting stuur.

Die Sadduseërs het deur hulle finansiële posisie en soepeler wetsinterpretasie nie vertroue by die Joodse volk ingeboesem nie. Ter wille van orde en belastings was Rome nogal uitgelewer aan die priesterleiding wat meestal deel van die Saddusese party was. Indien Jesus sou opgaan in hulle politieke sentimente, sou Hy die volk van Hom vervreem het.

Die kleiner georganiseerde gemeenskappe Fariseèrs wat hulle binding rondom die interpretasie van die Wet gevind het, het in die algemene opinievorming van Palestina 'n groot rol gespeel (vgl. Saldabini, 1988:56). Gedurende Jesus se tyd het die Fariseërs geweldige invloed onder die volk gehad. Jesus het egter ook nie sy lojaliteit aan hulle toegesê nie, hoofsaaklik omdat die Fariseërs die wet deur bykomstige mondelinge interpretasies van sy wesenlike betekenis gestroop het. Jesus moes egter deurgaans die politieke en sosiale aspirasies van die Sadduseërs en Fariseērs in gedagte hou sonder om Hom daarmee te vereenselwig. Alhoewel sy optrede politieke relevansie gehad het, was sy boodskap nie primer polities bedoel nie.

Aangevuur deur hulle religieuse ywer vir die wet, het die Selote nie geskroom om die wapen op te neem nie. Hulle optrede was egter polities destabiliserend. Jesus se ingesteldheid teenoor die Selote was eerder die van versoening aangesien een van sy dissipels uit die geledere van die Selote gekom het (Simon). Jesus het Hom egter nie met hulle politieke ideale verbind of vereenselwig nie (vgl. Hengel, 1989:38; Baumbach, 1968:17).

Die Esseners, daarenteen, het hulleself beskou as die suiwer oorblyfsel van die ware volk van God en padgegee uit Jerusalem uit protes teen die Hasmoneaanse hoëpriesters (vgl. Vermes, 1973:65). Polities het die Esseners by die Selote aangesluit tydens die finale Joodse oorlog teen Rome. Die Esseners se religieuse eksklusiwiteit het tot 'n sosiale en politieke meerwaardigheid gelei wat geen eerlike soeke na oplossings vir die Palestynse situasie was nie.

Eiebelang het by elk van dié groepe die oorheersende rol gespeel. Dit het daartoe gelei dat Jesus met 'n versplinterde samelewing te doene gekry het. Hy kon Hom eenvoudig net nie polities vereenselwig met enige van die groepe nie en het daarom 'n nuwe sosiale orde waarin geregtigheid en liefde heers, gevestig. Dit is seker nie vergesog om sekere tendense wat versplinterend ingewerk het op die aard en styl van bogenoemde groepe terug te vind in die Suid-Afrikaanse samelewing nie: bevoordeling op grond van sosiale posisie; nasionalistiese eksklusiwiteit wat neig tot meerderwaar- 
Was Jesus volgens Lukas se vertelling 'n politieke faktor?

dige afskeiding; politieke gewin op grond van religieuse motiverings; die vergroting van die gaping tussen ryk en arm; beleidsinterpretasies wat as dogma voorgehou word en wapengeweld in die naam van religie en nasionalisme, om enkele sake te noem.

\section{ALGEMENE LUKAANSE TIPERING VAN JESUS SE STANDPUNTINNAME}

\subsection{Beklemtoninge in die Lukasevangelie}

Lukas gee 'n kleurryke skildering van Jesus se houding en optrede ten opsigte van sosiale en politieke sake van daardie tyd. 'n Mens sou aan Lukas wou vra: was Jesus 'n aktivis of 'n passivis ten opsigte van sosiale en politieke aangeleenthede? Geselekteerde gegewens uit die Lukasevangelie voorsien 'n antwoord.

Lukas, volgens die Evangelieverhaal en Handelinge, teken Jesus se optrede en boodskap as God se ingrype in die menslike geskiedenis; die oorgaan vanaf die ou era van Israel tot 'n nuwe era; die Verlosser nie net van Israel nie maar ook van die universele mensdom. Die Lukaanse Jesusboodskap tintel van 'n verwagting oor die wederkoms (vgl. hoofstuk 17 en 21) en dit plaas die politieke en sosiale situasie in 'n eskatologiese raamwerk van waaksaamheid (vgl. Luk. 21: 34).

Lukas maak tog melding van politieke gebeure: Jesus weet byvoorbeeld dat Pilatus Galileërs doodgemaak het (13:1-3); Jesus is in 'n hewige konflik met Herodes Antipas (13:31-34); die presiese aanklagte teen Jesus word vermeld (23:2-5) en die rol van Herodes Antipas word presies weergegee (23:6-12). Bogenoemde voorbeelde kom slegs by Lukas voor (vgl. Sherwin-White, 1963:144 vv). Die indirekte gegewens oor politieke fasette is egter van groot belang, alhoewel moeilik om eksplisiet te definieer.

Conzelmann het byvoorbeeld aangetoon (1953:15 vv) dat die hoofprobleem in Lukas se teologie, rakende Jesus, die sogenaamde uitstel van die wederkoms was. Lukas probeer daarom om die situasie te interpreteer en plaas die klem op die huidige tydvak van die kerk. Conzelmann het verder gesê dat Jesus nie noodwendig in konflik met Rome was nie en dat sy onderdane, die Christene, daarom ook so 'n houding moes inneem. Dit beteken dat Lukas dan 'n "politieke apologie" geskryf het as verlengstuk van sy eskatologie. Uit onderstaande opname en bespreking sal dit egter duidelik word dat Lukas nie bloot 'n "politieke apologie" geskryf het nie, maar dat die betekenis van Jesus se verlossing ook politieke en sosiale implikasies vir die hede inhou.

Vervolgens word 'n paar fasette wat in die Lukasevangelie benadruk word, bespreek: 


\subsubsection{Die minderbevoorregtes}

Die Lukasevangelie het ' $n$ besondere sensitiwiteit vir die minderbevoorregtes. Dit kom reeds duidelik in die loflied van Maria in 1:52, 53 na vore. (1983-Vertaling.)

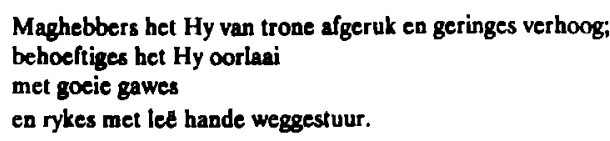

Die reinigingsoffer wat Jesus se ouers gebring het getuig ook van die minimum, naamlik "'n paar tortelduiwe of twee jong duiwe" (2:25).

Selfs Jesus se optrede in die sinagoge van Nasaret is veelseggend in die verband. Hy verwys in 4:18, 19 na Jesaja 61 en 58 en vereenselwig Hom met die sosiale aangeleenthede waarvan in dié gedeeltes sprake is:

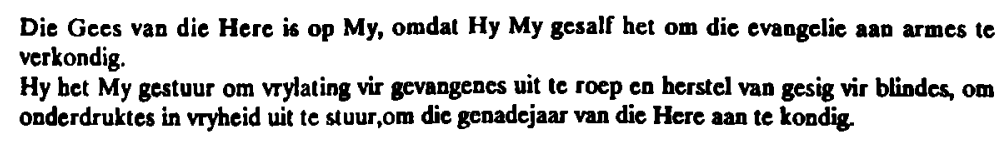

Hierdie gedeelte is 'n sinspeling op die Joodse sabbatjaar wanneer slawe vrygelaat moet word. Die armes, blindes en onderdruktes moet volgens die eksegetiese verband eerder letterlik opgeneem word (Schmid, 1960:112). Die armes verwys na diegene wat totaal afhanklik van God is, ook materieel. Hulle is geheel en al uitgelewer aan God in hulle verwagtinge.

In Lukas 6:20-21 vind ons 'n parallel met die Bergrede (Matt. 5:1-12). Dit is interessant om daarop te let dat Lukas nie die uitbreidings: "arm van gees", en 'vat nou "honger is en dors na geregtigheid", soos Matteus het nie. Uit die Lukaanse verband is dit duidelik dat die klem eerder op werklike armoede en honger val (vgl. verse 24-25 van dieselfde hoofstuk). Lukas teken Jesus definitief as sensitief en simpatiek teenoor diegene wat noodlydend en minderbevoorreg is (vgl. 7:22-23).

\subsubsection{Heidene en vroue}

Lukas plaas ook besondere klem op Jesus se betrokkenheid by heidene. Die genesing van die Samaritaanse melaatse saam met nege ander is 'n mooi voorbeeld (vgl. 17:1119). Die feit dat die cen Samaritaan omgedraai het om dankie te sê en dat hy "nie eers 'n Jood is nie" word besonder prominent genoem (vgl. ook 7:1-10; 8:26-33). Dit reflekteer tog dat daar nasionalistiese spanninge bestaan het. Jesus deurbreek dit! 
Jesus se sosiale betrokkenheid getuig deurgaans van universaliteit. Daarmee word ook gese dat Hy Hom met almal bemoei het, waaronder ook rykes en magtiges getel het (vgl. 6:29-32; 14:1-7; 19:1-10). Sake wat in die Lukasevangelie benadruk word, het 'n universele aard en dra 'n politieke bevrydende boodskap vir ons tyd.

\subsubsection{Rykes en rykdom}

Jesus se rigtinggewende standpunt oor rykdom en die rykes is vervat in sy uitspraak in Luk 12:15:

Pas op en wees op julle hoede vir elke vorm van gierigheid, want 'n

mens se lewe is nie afhanklik van die oorvloed van sy besittings nie.

In die daaropvolgende gelykenis word Jesus se houding dan verduidelik (vgl. 12:15-21). Daarvolgens is die ryk man nie oneerlik nie, maar bloot gierig. Hierdie ryk man verbreek ook geen wette nie, maar hy wil meer skatte he as wat hy werklik nodig gehad het. Jesus se houding is dat sy volgelinge se lewenstyl deur groter eenvoud en soberheid ten opsigte van besittings gekenmerk moet word (vgl. 12:22-34). Besit is as sodanig nie verkeerd nie, maar oortollige besit word heftig gekritiseer. En Jesus se eie leefstyl was nie in stryd daarmee nie (vgl. 9:58). Ons lees byvoorbeeld dat verskeie vroue "uit eie middele vir Jesus en die twaalf gesorg het" (8:3).

Wanneer Jesus waarsku teen oortollige besit, het die klem nie eensydig geval op die besit as sodanig nie, maar op oortolligheid en dit het gelei tot die oproep om te kan gee (vgl. 18:18-23). Die man oor wie dit in 18:18 gaan, kom uit die hoogste lae van die samelewing. Hy kan alleenlik volledig volgeling wees indien hy aan sy besittings die ondergeskikte plek toeken wat dit behoort te hê. Jesus se verwysing na die "oneerlike mammon" in 16:9 verwys na dié oortollige besit. Oortollig beteken dan dat die motiewe waarop besittings bekom is of waarvoor dit aangewend word, nie altyd bo verdenking is nie.

Jesus het die rykes werklik nie gespaar nie (vgl. 6:24; 16:14,15, asook 16:19-31). Dit word treffend verwoord in 18:24: "Hoe moeilik is dit tog vir mense wat ryk is, om in die koninkryk van God te kom."

'n Mens sou naderhand wou vra of Jesus as sodanig teen enige besit was. Nee, Hy prys selfs die rykes wat verstaan waaroor dit gaan en die surplus aan die armes gee (vgl. 18:26-30). Die barmhartige Samaritaan is nog ' $n$ mooi voorbeeld van so ' $n$ ingesteldheid (vgl. 10:30-37). Die duidelikste is waarskynlik die vertelling oor Saggeus (19:110). Saggeus sê: "Here, ek gaan die helfte van my goed vir die armes gee, en waar ek 
iets van iemand afgepers het, gee ek dit vierdubbel terug." Saggeus se beslissing bewoord die ideale. Hy slaag volgens Jesus daarin om teorie en praktyk by mekaar uit te bring (vgl. 19:9v).

'n Mens wil vra waarom sommige in Palestina ryk en ander arm was? Volgens alle aanduidings neem Jesus nie die rykes kwalik vir die armoede van die armes nie. Dit was ook nie noodwendig hulle skuld dat sommige $s$ arm was nie. Wat Jesus wel doen, is om 'n "program" van aksie te inisieer om die saak te hanteer. Eerstens, Hy beklemtoon ' $n$ besondere sensitiwiteit vir die armes. Verder kom dit daarop neer dat die rykes hulle surplus aan die armes moet uitdeel (vgl. 18:22). Die aangrypendste beginsel is egter dat die armes, kreupeles, verlamdes en blindes, (14:13v), dit wil sê die noodlydendes, verteenwoordigend is van die minderbevoorregtes. Die rykeres moet betrokke wees by die minderbevoorregtes.

\subsubsection{Onderdrukking en onreg}

Wat was Jesus se antwoord op onderdrukking en onregverdigheid?

Ten opsigte van wanpraktyke in die regspraktyke vind ons twee sydelingse toespelings op weduwees wat te na gekom is (vgl. 20:47 en 18:1-5). Jesus neem kragtig standpunt in teen ekonomiese misdryf onder die godsdienstige voorwendsel toe Hy die handelaars uit die tempel gejaag het (vgl. 19:45-46). Hy trek ook te velde teen diskriminasie teen vroue (vgl. 16:18 en 10:38-42).

\subsubsection{Nederigheid en diens}

In die nuwe Christus-era geld volgens Lukas ook 'n nuwe basis wat sosiale verhoudinge betref, naamlik nederigheid en toegewyde diens. In 9:47-48 word juis dit beklemtoon toe Jesus 'n kindjie demonstratief langs Hom laat staan en sê: "Elkeen wat hierdie kindjie in My Naam ontvang, ontvang My, en elkeen wat My ontvang, ontvang Hom wat My gestuur het. Wie die minste onder julle almal is, hy is die grootste." Grootheid le juis daarin om diegene en die gemeenskap wat nie "groot" is nie raak te sien! (Vgl. 14:711.)

Dieselfde geld van onselfsugtige diens. Jesus le die beginsel in 17:7-10 neer: "So is dit dan met julle: as julle alles gedoen het wat aan julle opgedra is, sê dan: 'Ons is slawe wat niks verdien nie. Ons het gedoen wat ons verplig was om te doen." So 'n gesindheid vorm die basis vir 'n nuwe sosiale verantwoordelikheid. Selfs die styl van konings kom wat dit betref onder skoot (vgl. 22:24-27): "By die nasies is dit s6: konings speel 
oor hulle baas, en dié wat gesag afdwing, laat hulleself weldoeners wees. Maar by julle moet dit nie só wees nie. Inteendeel, die belangrikste onder julle, moet soos die geringste wees, en die een wat die leier is, soos die een wat dien."

Alle sosiale patrone word noodwendig geraak, ook op staatkundige gebied, as die beginsels van nederigheid en diens kunsekwent toegepas word. 'n Nuwe gemeenskapsgesindheid kom tot stand wanneer die nuwe Christushouding realiseer.

\subsubsection{Geweld}

Kan geweld dan nie aangewend word om sosiale hervorming teweeg te bring nie? Alhoewel Lukas nie eksplisiet die term geweldloosheid gebruik nie, kom dié aspek tog in beginsel voor. Geweldloosheid funksioneer vanuit die liefde en in waarheid. In 6:2731 word Jesus se "beginsels" van "geweldloosheid" uitgespel:

Julle moet julle vyande liefhé; doen goed aan die mense deur wie julle gehaat word; seen die mense deur wie julle vervloek word; bid vir die mense deur wie julle sleg behandel word.

Alhoewel Jesus bewus moes wees van die Selote se opbou om Rome met geweld omver te werp, was sy beleid eerder: "Behandel ander mense soos julle self behandel wil word." (6:31)

Jesus was goed bekend met die politieke leiers se geweldadige metodes van geweld om hulle doeleindes te bereik: Pilatus wat die Galileërs wat besig was om hulle offerdiere te slag, doodgemaak het (13:1); Johannes die Doper se gevangeskap en ongelukkige teregstelling (vgl. 9:19-21) en die Fariseërs se waarskuwing aan Jesus dat Herodes Antipas Hom wil doodmaak.

Jesus leer egter dat sulke geweld met gelatenheid begroet moet word: "As iemand jou op die een wang slaan, bied hom ook die ander een aan" (6:29). In dié verband word ook groot klem op vergifnis geplaas (11:4). Die Christussaak is groter as eiebelang en eie voorkeur.

Jesus was 'n geestelike leier wat sake geestelik wou oplos! Die stelling in 22:36: "En wie nie 'n swaard het nie, moet van sy klere verkoop en een aanskaf" laat egter 'n vraag ontstaan - is dit nie 'n ope uitnodiging tot geweld nie? Nee, "rather the saying is a call to be ready for hardship and self sacrifice" (Marshall, 1978:825). Hulle moet enigiets verwag! Dat Jesus se leer ooreenkom met sy dade, spreek vir sigself in sy kruiswoord (23:34): "Vader, vergeef hulle, want hulle weet nie wat hulle doen nie"I 


\section{JESUS SE SPESIFIEKE IIOUDING TEN OPSIGTE VAN SEKERE GROEPE}

\section{S.1 Jesus en Herodes Antipas}

Jesus se siening van Herodes Antipas is saamgevat in 13:31-33. Toe die Fariseêrs Jesus gewaarsku het dat Herodes Hom wil doodmaak, antwoord Hy: "Gaan sê vir daardie jakkals: Kyk, vandag en môre dryf Ek nog duiwels uit en maak Ek mense gesond, maar op die derde dag sal Ek my werk klaar maak." Jesus beoog om eers sy openbaringswerk te voltooi ten spyte van Herodes se planne. Aan Herodes heg Jesus volgens bogenoemde aanhalings in elk geval 'n negatiewe konnotasie.

\subsection{Jesus en die priesterhoofde}

Gedurende sy bediening in Galilea was dit veral die Fariseërs met wie Jesus in argumente betrokke was (vgl. 6:7.8; 11:53-54), maar nadat Jesus Jerusalem binnegegaan het, knoop Hy die stryd aan met die priesterhoofde en hulle meelopers, die oudstes en Skrifgeleerdes. Die priesterhoofde was ongetwyfeld die gevaarlikste opponente (vgl. 19:47). Jesus se opruiming van die tempelvoorhof (19:45-46) het waarskynlik die priesterhoofde se persoonlike aansien by die volk asook hulle eie ekonomiese posisie 'n slag toegedien (vgl. Horn, 1983:67).

Met reekse gelade vrae probeer die priesterhoofde om Jesus se posisie te ondermyn: Wat was die bron vir sy gesag? (20:2); is dit reg om aan die keiser belasting te betaal? (20:20 e.v.); watter van die sewe mans kry die vrou met wie hulle op aarde getroud was na die opstanding? (20:27 e.v.). Jesus antwoord nie een van hierdie vrae direk nie. Ons merk egter 'n onrustigheid by die priesterhoofde, 'n vrees om hulle politieke seggenskap by die Joodse volk te verloor indien Jesus se aanhang verder sou toeneem.

Alhoewel Jesus nie direk aan die politiek van sy tyd deelgeneem het nie, was Hy 'n politieke faktor met wie rekening gehou moes word! Jesus se gelykenis oor die boere en die wingerd (20:9-19) illustreer verder die negatiewe posisie van die priesterhoofde. Lukas sê uitdruklik in vers 19 dat die priesterhoofde terdeë besef het dat Jesus op hulle sinspeel as die huurders van die wingerd wat die slawe van die eienaar verdryf het en die seun doodgemaak het. Enige instansie wat nie aan die geestelike voortgang van die koninkryk van God ruimte of steun bied nie, kan ook polities 'n gevaar wees! 
Was Jesus volgens Lukas se vertelling 'n politiekc faktor?

\subsection{Jesus en die Romeine}

Dit kan aanvaar word dat die beginsel waarvolgens Rome regeer het dié van mag was. Mense is onderwerp en onder beheer gehou deur magsuitoefening, veral in die provinsies. Magstoepassing en selfverryking het aan die basis van hulle regeerstyl ten grondslag gele, (vgl. Cassidy, 1978:88 e.v.). Jesus se standpunte teenoor geweld, sowel as selfverryking ten koste van andere, is alombekend.

In 20:21 e.v. kom die agente van die priesterhoofde om navraag te doen of 'n mens belasting aan die keiser moet betaal. Jesus antwoord: "... gee dan aan die keiser wat aan die keiser behoort, en aan God wat aan God behoort". Beteken dié uitspraak dat Jesus vir die Romeinse owerhede 'n lansie breek? (Vgl. Ellis, 1966; Grundmann, 1971.) Andere meen dat Jesus gekant was teen belasting aan die staat (vgl. Brandon, 1967; Kennard, 1950). Hierdie uitspraak van Jesus mag nie geïsoleerd beoordeel word nie, maar moet saam met die res van die Lukasevangelie gelees word. Jesus vra die agente toe om 'n denarius-muntstuk met die kop van die keiser daarop. Dit was ongewoon omdat die denarius nie die eintlike munt was waarmee die belasting betaal is nie (eerder 'n Attiese dragma). Die denarius het egter die keiser se beeld (Augustus of Tiberius) vertoon. Dié vraag het hulle as goeie Jode alreeds in 'n verleentheid gestel omdat selfs die hantering van 'n muntstuk met die keiser se kop op as ongewens deur die konserwatiewe Jode beskou is.

Was Jesus verder net besig om die verpliginge teenoor die keiser naas die teenoor God op 'n gelyke basis te plaas? Stauffer meen wel so (1957:27). Die verpligtinge teenoor God en die keiser kan sekerlik nie op 'n gelyke basis geplaas word nie ondat alles aan God behoort. Jesus het in elk geval nie die Selote bevredig nie, ook nie die priesterhoofde nie (vgl. 20:26). Sy boodskap is kort en kragtig dat as iemand onder die staatsvorm van 'n keiser leef, sodanige belasting betaal moet word, dit wil sê, die verpligtinge nagekom moet word.

In 22:24-27 het Jesus die owerhede getipeer as mense wat gesag afdwing (hoi exousiazontes). In dié verband is die konnotasie negatief. Dit word bevestig volgens 21:12-15 waar die dissipels gewaarsku word dat hulle voor "konings en goewerneurs" gesleep sal word. Dit impliseer 'n evangeliese pad van konflik met owerhede wat vanuit 'n magsuitoefening onbillike eise stel.

\section{WAS JESUS 'N POLITIEKE FAKTOR?}

Samevattend: Jesus was nie 'n politieke aktivis nie; Hy was egter ook nie net 'n passiewe toeskouer nie maar'n geestelike deelnemer aan die politieke en sosiale orde. 
Hy het konflik vermy maar kritiseer die tipiese Romeinse magstyl asook selfverrykingstrategie. Sy korrektief op die samelewing was nie primér polities van aard nie maar het vanuit 'n nuwe geestelike betrokkenheid politieke effek gehad. Hy was dus polities 'n beduidende faktor.

Was Hy 'n gevaar vir die Romeinse owerheid? Sonder om die gebeure rondom sy verhoor en teregstelling te betrek, kan enkele gevolgtrekkings uit die Lukasevangelie gemaak word.

Alhoewel Jesus konsekwent die gebruik van geweld teen persone afgekeur het en ook nie 'n Seloot was nie, was Hy tog 'n bedreiging vir die owerhede. Sy demonstrasie van die Goddelike bedoeling wat liefde en nederigheid behoort te wees, het 'n liefdesamelewing tot stand gebring wat deur die owerhede met vrees bejeën is. S6 'n samelewing berus nie op 'n menslike magsbasis nie maar op 'n Goddelike kragbasis.

Hy het die sosiale patrone van sy tyd ingrypend verander - veral ten opsigte van die armes en rykes, die vroue en die vreemdelinge. Hy het te velde getrek teen oorheersing ter wille van uitbuiting. Hy het geweld afgekeur en stel in die plek daarvan nederigheid en diens as basis van alle verhoudinge. Jesus was nooit in diens van die owerhede om hulle politieke of sosiale patrone te sanksioneer of selfs te propageer nie. Hy het egter ook nie soos die Selote gepoog om aktivisties die strukture af te breek nie. Sy appèl het 'n innerlike gesindheidsverandering behels om die ware sosiale orde te dra 'n gesindheid van diens en nederigheid. En dit kom kort by die priesterhoofde en Fariseěrs, asook by die regeerders, veral Herodes Antipas.

Sy geestelike gemotiveerdheid, die feit dat $\mathrm{Hy}$ God se nuwe era van verlossing gebring het, het Jesus sodanig gedryf dat dit ook op sosiale en politieke terreine sigbaar moes word. Ook dit behoort die styl van Christelike geloofsgroepe en kerke te wees. Die beginsel van waaruit Jesus funksioneer, is dat Sy verhouding met die Vader ook Sy sosiale en politieke betrokkenheid bepaal het (vgl. 12:22-32). In sy mees kritieke oomblikke het Hy gebid (vgl. 3:21; 6:12; 22:41-46, asook 9:18; 9:29 en 22:32). Lukas slaag meesterlik daarin om by krisismomente hemel en aarde aan mekaar te laat raak!

'n Belangrike gevolgtrekking is dat Jesus die eng eksklusiwisme van die Jode deurbreek het. Hy het eerder God se kosmiese bedoeling kom illustreer. Jesus het Hom enersyds nie met die Herodiane wat die owerheid kritiekloos gesteun het, vereenselwig nie. Hy het egter, andersyds ook nie aktivisties deel geword van die Selote (vgl. Matt. 26) wat met nasionalistiese geweld alle mag vir die Joodse volk wou opeis nie. Dit is verder treffend dat Jesus ook nie opgegaan het in die Esseense mentaliteit om hulle in afsondering te onttrek van die samelewing nie. 
Was Jesus volgens Lukas se vertelling 'n politieke faktor?

Jesus het volgens die Lukasevangelie deur nederigheid en diens 'n nuwe liefdesgemeenskap gevestig wat juis ook op politieke, sosiale en ekonomiese terreine sigbaar moes word. Ook in die Suid-Afrikaanse samelewing kan nie genoeg gemaak word van 'n gehoorsaamheid aan die eis van die liefde, op pad na vrede en stabiliteit vir al die inwoners van die land nie.

\section{BIBLIOGRAFIE}

BAUMBACH, G. 1968. Die Zeloten - Die geschichtliche und religionspolitische Bedeutung. Bibel und Litungie, 41:2-25.

BAMMEL, E. 1984. The revolution theory from Reimarus to Brandon (In Bammel, E. \& Moule, C.F.D. ed., Jesus and the politics of his day. Cambridge : Cambridge University Press. p. 1168)

BRANDON, S.G.F 1967. Jesus and the Zealols. Manchesicr: Manchester University Press.

BROWN, J.P 1969. The liberaled zone. Richmond : John Knox

CASSIDY, R.J. 1978. Jesus, politics and society. New York: Orbis Bcoks.

CONZELMANN, H. 1953. Die Mitte der Zeit. Tubingen : Mohr.

CULLMANN, O. 1970. Jesus and the revolutionaries. (Trs. G. Pulnam). New York : Harper \& Row.

DE VEAUX, R. 1965. Ancient Isracl. 2 ed. Trs. J. McHugh London : Darton, Longman, Todd.

ELLIS, E.E. 1966. The Gospel of Luke. London : Nelson.

GRUNDMANN, W. 1971. Das Evangelium nach Lukas. Berlin : Evangelische Verlaganstalt.

HARRELSON, W. 1962. Law in the Old Testament, (In Bultrick, G. ed., The Interpreter's Dictionary of the Bible, 3. New York Abington. p. 77-89.)

HENGEL, M 1989. The Zealots. Investigation into the Jewish freedom movement in the pcriod from Herod I until 70 A. D. Trs. D. Smith. Edinburgh : Clark.

HORN, F.W. 1983. Glaube und Handeln in der Theologie des Lukas. Gottingen : Vandenhoeck.

JEREMIAS, J. 1969. Jerusalem in the time of Jesus. Trs. F.H. Cave; C.H Cave. Philadelphia : Fortress.

JOSEPHUS (1930). Jewish Anliquities. Trs H. Thackeray et al. New York : Locb Classical Library.

JOSEPHUS (1928). The Jewish War. Trs H. Thackeray et al. New York : Locb Classical Library.

KENNARD, J.S. 1950. Render to God. A siudy ol the Iribule passage. New York : Oxford University Press.

MARSHALL, 1.H. 1978. The Gospel of Luke. Excter : Paternoster Press.

McCOWN, C.C. 1962. Geography of Palestine. (In Bullrick, G. ed., The Interpreter's Dictionary of the Bible, 3. New York: Abington. p. 626-639.)

NEUSNER, J. 1973. From politics to piety: The emergence of Pharisaic Judaism. Englewood Cliffs : Prentice-Hall

PAUPERT, J.P. 1969. The politics of the Gospel. New York: Hols

RICHARDSON, A. 1973. The political Christ. Philadelphia : Westminster Press

SALDARINI, AJ. 1988. Pharisces, Scribes and Sadducees in Palestinian society. Edinburgh : Clark.

SHERWIN-WHITE 1 A.N. 1963. Roman society and Roman law in the New Testament. Oxford: Clarendon Press.

SCHMID, J. 1960. Das Evangelium nach Lukas. 4 ed. Regensburg : Pustet.

STAUFFER, E 1957. Jerusalem und Rom im Zeitalıcr Jesu Christi. Eern : Francke.

THIESSEN, G. 1987. The shadow of the Galilean. The quest of the historical Jesus in narrative form. Trsl. J. Bowden. London : SCM.

VERMES, G. 1973. Jesus the Jew. London : Collins.

YODER, J.H. 1972. The politics of Jesus. Michigan : Eerdmans 